\title{
Introduction: Early Catholic Orientalism and the Missionary Discovery of Asian Religions
}

\author{
Robert Trent Pomplun \\ The University of Notre Dame, IN, USA \\ rpomplun@nd.edu \\ Joan-Pau Rubiés \\ ICREA \& Universitat Pompeu Fabra, Spain \\ joan-pau.rubies@upf.edu \\ Ines G. Županov \\ CNRS (CEIAS/E HESS), Paris, France and Centre for Social Sciences \\ and Humanities (New Delhi), India \\ zupanov@ehess.fr
}

\begin{abstract}
New encounters in America, Africa, and Asia facilitated the "discovery" of non-Biblical religious traditions that were distinct from the ancient paganism known to Christian humanists and antiquarians from classical sources and patristic literature. Although Hinduism, Buddhism, and Confucianism did not exist as concepts in the early modern period, the three articles in this special issue illustrate the learning process by which a number of influential and pioneering Catholic missionaries came to distinguish these various traditions from each other. We argue that they did not simply "invent" new religions arbitrarily: instead, on the basis of the very broad categories of true religion and idolatry, they engaged in some close interaction and "dialogue" — albeit usually polemical - with local religious elites and their writings, including Eastern Christians. In addition, in the case of the Jesuits in particular, we note that these various engagements were often connected events that influenced each other in important ways, from India to Japan, from Japan to China, and from all these to Tibet.
\end{abstract}




\section{Keywords}

Catholic Orientalism - religious encounters - early modernity - Jesuit missions Asian religions

\section{Introduction}

Recent publications have increasingly highlighted the importance of the early modern European discourse on gentile religions. In particular, new encounters in America, Africa, and Asia facilitated the "discovery" of non-Biblical religious traditions that were distinct from the ancient Mediterranean paganism known to humanists and Christian antiquarians from classical sources and patristic literature. ${ }^{1}$ The fundamental contribution of empirical and polemical accounts by Catholic missionaries - often, but not exclusively, the Jesuits - has often been emphasized. While some missionary ethnographies, such as the work of the Franciscans in New Spain, were essential to documenting the religion of the New World before the Spanish conquest, the continuous exploration of the living religious traditions of literate societies in Asia (in India, Tibet, China, Japan, and South-East Asia) exercised perhaps the strongest intellectual impact in early modern Europe. ${ }^{2}$ Even those materials that remained unpublished often circulated in manuscript and constituted a "Catholic archive"

1 For the general problem see Peter N. Miller, "Taking Paganism Seriously: Anthropology and Antiquarianism in Early-Seventeenth Century Histories of Religion," Archiv für religiongeschichte, 3 (2001): 183-209; Guy Strousma, A New Science: The Discovery of Religion in the Age of Reason (Cambridge, MA, 2010); Joan-Pau Rubiés, "From antiquarianism to philosophical history: India, China and the World History of Religion in European Thought (160o-1770)," in Antiquarianism and Intellectual Life in Europe and China, 1500-1800, eds. Peter N. Miller and François Louis (Ann Arbor, 2012), 313-367; On the "discovery" of Hinduism see the pioneering work of Peter J. Marshall ed., The British Discovery of Hinduism in the Eighteenth Century (Cambridge, 1970); Brian K. Pennington, Was Hinduism Invented? Britons, Indians, and Colonial Construction of Religion, (Oxford, 2005); and (for the earlier phases) JoanPau Rubiés, "The Jesuit Discovery of Hinduism: Antonio Rubino's Account of the History and Religion of Vijayanagara (1608)," Archiv für Religionschichte, 3 (2001): 210-256; For the "discovery" of Buddhism the classic studies are Philip C. Almond, The British Discovery of Buddhism (Cambridge, 1988); Donald S. Lopez, Prisoners of Shangri-La: Tibetan Buddhism and the West (Chicago, 1998); and for the earlier phases Urs App, The Cult of Emptiness: The Western Discovery of Buddhist Thought and the Invention of Oriental Philosophy (Kyoto, 2012). On the European "discovery" of Confucianism see Virgile Pinot, La Chine et la formation de l'esprit philosophique en France, 1640-1740 (Paris, 1932), still valuable despite its age; and David Mungello, Curious Land:Jesuit Accommodation and the Origins of Sinology (Honolulu, 1985).

2 For this impact see especially Urs App, The Birth of Orientalism (Philadelphia, 2010). 
which, as Ângela Barreto Xavier and Ines G. Županov have emphasized, was sometimes silently appropriated by subsequent Protestant scholars in order to develop their own version of colonial Orientalism. ${ }^{3}$

In the context of a post-colonial historiography often suspicious of the assumptions of nineteenth century imperialism, many scholars rightly questioned the ethnocentric undertones of the concept of "discovery," which should only be used - as we do here-in a relative sense. In its more radical versions, influenced by the work of Edward Said, many contributions developed the notion that Europeans did not simply recognize pre-existing religions, but instead "invented" or "manufactured" them, exporting a Christian concept of religion that failed to take account of the complexity and plurality of the local traditions they were interpreting. ${ }^{4}$ It is certainly the case that in an early modern context the concepts of Buddhism, Hinduism, and Confucianism - to mention three of the most relevant examples - can be anachronistic, if we ignore this plurality and complexity. On the other hand, the notion of "invention" can paradoxically become as Eurocentric as that of discovery, since it negates the fact that these traditions had their own self-understanding as distinct "laws" an independent history which was, at times, geared to strengthen internal coherence by introducing distinctions both within and against the exterior. We have, for example, the concept of "buddhadharma," the law or teachings of Buddha, well before any European coined the concept of "Buddhism" as a religion comparable to Christianity. As the articles in this collection show, these self-definitions were often recognized by outsiders, so that external distinctions, far from being arbitrary, were often grounded on internal ones, albeit not always entirely faithfully. For example, the Jesuits, as Rubiés notes in his contribution, by 1556 had learnt that in Japan there was a sect called "Buppō" (Buddhist teaching, or law of Buddha) which had originally arrived from China

3 Ângela Barreto Xavier and Ines G. Županov, Catholic Orientalism: Portuguese Empire, Indian Knowledge (16th-18th centuries), (Oxford, 2015).

4 For a notorious example see Lionel Jensen, Manufacturing Confucianism: Chinese Traditions and Universal Civilization (Durham, N.C., 1997). For a critique see Nicolas Standaert, "The Jesuits Did NOT Manufacture 'Confucianism," East Asian Science, Technology, and Medicine 16 (1999): 115-132. In the field of Hinduism, see the critique of the notion of a British colonial invention by David N. Lorenzen, "Who Invented Hinduism?" Comparative Studies in Society and History 41, no. 4 (1999): 630-659; Will Sweetman, "Unity and Plurality: Hinduism and the Religions of India in Early European Scholarship," Religion, 31 (2001): 209-224; and Joan-Pau Rubiés, "Reassessing 'the Discovery of Hinduism': Jesuit Discourse on Gentile Idolatry and the European Republic of Letters," in Intercultural Encounter and the Jesuit Mission in South Asia (16th-18th Centuries), eds. Anand Amaladass and Ines Županov (Bangalore, 2014), 113-155; among others. 
and was distinct from Shintō, the native cult of their old gods, or "kamis." ${ }^{5}$ Not unlike the religion of the Brahmans in India, this sect was understood to be remarkably plural (it had nine "sects"), but with an identifiable core of common origins, scriptural traditions, families of deities, and doctrines. Distinct religious traditions were also often connected to specific religious elites claiming authority, such as the Brahmans in India, and various orders of monks in the case of Buddhism. ${ }^{6}$ The European interpretation of the specific sect of the literati in China-what we now call Confucianism-followed a similar process: a distinct tradition with peculiar doctrines and ritual practices was quickly identified by the Jesuit missionary Matteo Ricci as belonging to a specific intellectual elite, on the basis of an existing representation of religious plurality within China, where for centuries it was common to talk about the "three teachings" (San Jiao) of Confucius, Laozi, and Saakyamuni. ${ }^{7}$ From a sixteenthcentury perspective, what distinguished Christians from their hosts in Japan or China was less the idea that there were various distinct religions than deep resistance to syncretic or complementary combinations.

It remains nonetheless important to bear in mind that neither Hinduism nor Buddhism, nor Confucianism and neo-Confucianism for that matter, existed as concepts in the early modern period. The generalized use of "isms" to describe all religious systems and ideologies in fact belongs to the first half of the nineteenth century, and in previous centuries most Europeans understood Asian religions very broadly, as varieties of "modern" (as opposed to ancient)

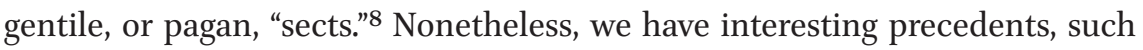
as the use of the word "Brahmanism" (Bramanismo) by the Jesuit Gonçalo Fernandes Trancoso in the early seventeenth century, when collecting local

5 "Sumário dos erros en que os gentios do Japão vivem," in Documentos del Japón 1547-1557, ed. J. Ruiz de Medina (Rome, 199o), 659: "there is another sect called bupoo, and it is divided in eight or nine sects" (our translation). The Sanskrit equivalent to Buppō would be buddhadharma, and in China, fojiao.

6 The fact that Brahmans were a religious elite peculiar to India did not of course mean that they were the only native religious elite in India, where there were also Jain monks, Sikh gurus, Sufi saints, Christian priests, etc.

7 The idea of three teachings, rujiao (Confucianism), daojiao (Daoism), and fojiao (Buddhism), dates from as early as the establishment of Buddhism in the Tang period, and was often the subject of pictorial representations emphasizing complementarity and harmony, albeit (in not a few cases) also establishing a hierarchy, usually with Confucius as the central figure. Syncretic tendencies ("the three teaching are one") were important in the Yuan and Ming periods, and were observed by Matteo Ricci. See Timothy Brook, "Rethinking Syncretism: The Unity of the Three Teachings and their Joint Worship in Late-Imperial China," Journal of Chinese Religions, 21 (1993): 13-44.

8 The suffix "-ism," of Greek and Latin origins, is of course older, and can be attested in modern European languages from the seventeenth century. 
written evidence for his dispute about missionary methods against fellowJesuit Roberto Nobili. ${ }^{9}$ In any case, whether by using the suffix "ism" or not, the process of distinguishing various Eastern religious and philosophical traditions was evident at the height of the Enlightenment. For example, the Encyclopédie of D'Alembert and Diderot carried articles such as "Judaisme," "Platonisme," or "Paganisme," albeit not "Hinduisme," "Buddhisme," or "Confucianisme." Instead, it had "Philosophie des Indiens," "Philosophie des Japonois," and "Philosophie des Chinois," in which the teachings of the "brachmanes" and "la doctrine de Siaka \& de Confucius" were distinguished and analyzed, even noting some of their mutual interactions (i.e. suggesting that the doctrines of Shaka had "infected" all the others).

Clearly, then, early modern Europeans would normally distinguish the philosophy of the Brahmans of India from that of the followers of Shaka (Buddha) in Japan and China, and that of Confucius in China. They would also acknowledge that these religious traditions were internally divided, and even that they could be combined in a syncretic fashion. What the evidence of the three articles in this special issue illustrates is the learning process by which a number of influential and pioneering missionaries came to distinguish these various traditions from each other. However, this "learning process" was not driven by simple scientific curiosity. Rather, ideological agendas also encouraged false connections and arbitrary historical claims. This can be illustrated by the efforts of the Jesuit antiquarian Athnasius Kircher in the seventeenth century (who had access to many of these early sources) to identify all the gods of Asia, and its various religious teachers, with deities and historical figures that could be traced back to Ancient Egypt (so that Zoroaster was Ham, the son of Noah; Confucius taught the same natural monotheism as Hermes Trismegistus; and Buddha became Rama, a "sinful Brahmin" who had learnt the doctrines of Pythagoras and spread them across all Asia)..$^{10}$ In this manner, Kircher constructed, through superficial analogies, a universal system of religion and idolatry - the authentic teaching and its degeneration. In a similar vein, the so-called "figurists" in China, missionaries like Joachim Bouvet and Joseph de Prémare, in subsequent decades looked for traces of the universal sacred history and Christian revelation in the I Ching (Yijing) and other Chinese classics. These positions were not mainstream (in fact, the Jesuits in Europe sought to suppress these views), but they illustrate the fact that we do not seek to

\footnotetext{
9 Gonçalo Fernandes Trancoso, Tratado do Pe. Gonçalo Fernandes Trancoso sobre o Hinduísmo, edited by Josef Wicki (Lisbon, 1973), 3, 36-37, 301, 305.

10 Athanasius Kicher, China Monumentis ... Illustrata (Amsterdam, 1667).
} 
describe a linear process, and that even within the same religious order, different interpretations were often proposed and contested.

Crucially, we wish to insist that when Catholic missionaries came to distinguish various traditions, they did so by engaging in some close interaction and "dialogue" —albeit usually polemical — with local religious elites and their writings, whether Brahmans, Buddhist monks, or Confucian literati. ${ }^{11}$ However, these various engagements were not always separate events, isolated from each other. Rather, considering the evidence from the three articles, we would like to claim that they sometimes influenced each other in important ways. That is to say, Jesuit missionaries, the main focus of our analysis, did not at first approach what we now call Hinduism, Buddhism, and Confucianism in isolation from each other. Instead, their understanding was the result of multiple and successive encounters in which they made use of comparison, analogy, and distinctions. In that way the assumptions, challenges, and solutions forged in one missionary context were often carried over and adapted in the next-from India to Japan, and from Japan to China for example. In this process, they generated the idea that there were different religious traditions that could be distinguished from each other, although all of them remained in some way or another "idolatrous." For example, Rubiés emphasizes the importance of the Jesuit interpretation of Japanese Buddhism in the second half of the sixteenth century, from the arrival of Francis Xavier to the mature synthesis of Alessandro Valignano. Japan became a crucible because the efforts by missionaries to come to terms with the esoteric doctrines of Mahāyāna Buddhism, notably atheism, generated a set of distinctions between theistic and non-theistic forms of "idolatry" that affected the interpretation of all major religious traditions in India and East Asia. In this manner, the generic concept of gentile idolatry (a category driven by a principle of exclusion rather than any doctrinal analysis) was transformed into a series of distinctive religious traditions. There was a clear understanding that Japanese Buddhism was a transnational system which had its roots in China and elsewhere in South Asia, and this decisively influenced the efforts by Matteo Ricci to construct Confucianism as a distinct Chinese tradition which was originally theistic, in opposition to the pervasive influence of a pan-Asian form of Buddhist "idolatry."

However, these essays also show that these interactions were not limited to "modern paganism." As Županov shows, the non-European Christian could

11 The concept of cultural dialogue is no less problematic than those of "discovery," "invention," and "religion." For a discussion see Joan-Pau Rubiés, "The Concept of Cultural Dialogue and the Jesuit Method of Accommodation: between Idolatry and Civilization," Archivium Historicum Societatis Iesu 74, n. 147 (2005): 237-280. 
also be an "other;" an indispensable challenge to the assumption (still present today in some historiography) that Western European civilization and Christianity are the same thing. Moreover, Županov argues that engagement with Eastern Christians in South India-the Syriac churches of Malabar, which Catholic missionaries believed had been contaminated with Nestorian heresies - decisively influenced the experiments with accommodation of civil customs led by Roberto Nobili in Madurai, traditionally understood as one of the most creative as well as controversial intellectual engagements with Hinduism in the context of the Christian missions of the seventeenth century. The story to be told therefore is not one which isolates gentile religions as an object of the European imagination, and then tries the disentangle the process by which a series of distinct "religions" were identified or constructed. Instead, these essays show how engagement with religious diversity, and the various efforts to historicize and theologize it, were often deeply connected to the early modern crisis of Christian identities in Europe, one which manifested itself primarily, but not exclusively, through the Protestant and Catholic Reformations. Here we argue that confrontation with concepts and practices encountered in partibus infidelium contributed decisively to the construction of new ideas of Christianity in contexts that were often doubly polemical, internally as well as externally. ${ }^{12}$

In his contribution, Robert Trent Pomplun develops this argument further with reference to the interpretation of Tibetan Buddhism by the Jesuit Ippolito Desideri early in the eighteenth century. However, the identities and assumptions he seeks to question are not simply those of the early modern Catholic missionaries in their efforts to construct an image of a false religion through Christian vocabulary and scholastic categories (including the role of the Devil), but also those of more recent scholars in the field of religious studies. His argument offers another illustration of how all the terms used by scholars to address the history of the missions or the discovery of Asian religions-Hinduism, Buddhism, Confucianism, religion, law, antiquity, atheism, superstition, sect - while not quite "manufactured" were still entangled in semantic fields of vague or uncertain scope. Despite Desideri's fundamental hostility to Buddhism, Pomplun identifies a number of "scholastic" assumptions that Desideri was able to share with his Buddhist opponents in Tibet,

12 An interesting parallel could be drawn with the impact of the confrontation of Europe's religious minorities, Jewish and Muslim, especially after failed attempts at mass conversion in the Iberian Peninsula. For a recent re-assessment see Mercedes García Arenal and Gerard Wiegers, eds, Polemical Encounters: Christians, Jews, and Muslims in Iberia and Beyond (University Park, PA, 2019). 
who practiced their own kind of scholastic disputations. The interesting point is that these cross-cultural intellectual analogies are often at odds with those assumed by a historiography dominated by Protestant assumptions of "what is religion," notably the tendencies to privilege belief over practice, and to dismiss the capacity of gentile barbarians to generate their own philosophical traditions. In this article, as in the other contributions to this special issue, the retrieval and nuanced interpretation of the Catholic archive-with all its biases-makes it possible not only to illuminate the process by which actual encounters shaped the early modern understanding of religion in its global diversity: it also adds a valuable historical perspective to the current debate about the nature of religion.

\section{Acknowledgements}

The papers for this special issue have their origin in a workshop on The Early Modern Catholic Invention of "Oriental" "Religions" that took place at the University of Texas at Austin, in January 2018. We are grateful to Sumit Guha and Jorge Cañizares-Esguerra for convening the event, and also to the other participants of the conference for a very stimulating debate. 